\title{
The Liturgical Service of the Hegumen According to the Canons of the Constantinople Council of
} 1276

\author{
Maria Korogodina \\ Researcher, Saint-Petersburg University, St.Petersburg Russia \\ mkorogodina@rambler.ru
}

\begin{abstract}
Metropolitan of Kiev Cyril the Second and Russian bishops sent a bishop of Saray to Constantinople with questions concerning the most difficult problems of church management and features of liturgical service. The canons were translated into Russian probably in the 14 th century, and several new questions-and-answers were added during the translation. There are several canons about hegumens and the features of their liturgical service in the Russian text. They include questions about the tonsure of a dying man; the singing of the Trisagion with ripidia; the service of the Prothesis (Proskomedia); the feast of the Exaltation of the Holy Cross; and the final prayers at the Divine Liturgy. The research let to purpose that all of these articles were added by Russian authors, so they are the evidence of the liturgical service and monastic life in Russia in the 14 th century.
\end{abstract}

\section{Keywords}

Constantinople Council of 1276 - Kiev Metropolis - canon law - hegumen

Russian liturgical books did not pay any attention to the liturgical service of a hegumen until the end of the 13th century. Special Euchologia for bishops or

1 The author expresses the deepest gratitude to Alexandr Andreev for improving her English. The research was carried out with a financial support of the Russian Science Foundation, project 20-18-oo171 "Moscovia \& Ruthenia in the 15th-17th centuries: mutual influences of written traditions in liturgy, canon law, the educational system, and theology". 
hegumens did not exist; and liturgical rubrics describing the features of the Liturgy and the daily and annual cycles of services led by a hegumen were absent from the manuscript liturgical books. Some questions concerning the specific character of a hegumen's and a bishop's liturgical ordo were examined in detail in the canons of the Constantinople Council that answered the questions of Bishop Theognost of Saray in 1276. ${ }^{2}$ These canons are known in Greek and in Russian, so they describe the different functions of clergymen in the second half of the 13th century both for Russian clergy and Greek bishops. However the canons of the Council of Constantinople were not accepted in Russia in the 13th century. Probably the Union of Lyon (1274-1282) ${ }^{3}$ was the cause of the refusal to accept the canons in Russia, as this short alliance with Rome left a mark on many of the replies of the Greek bishops. These replies were contrary to the settled traditions of the Russian Church and to the canons approved by a Russian Council that had taken place in $1273 .{ }^{4}$ Presumably a Russian translation of the Greek canons was made no earlier than the middle of the 14th century; the Russian version of the canons includes a number of additions by a translator or editor: while the single known Greek version includes 15 canons, the oldest Russian version consists of 33 canons. Some of the Russian canons must have existed originally in the Greek text but were not preserved in Greek; others were written by Russian authors. This complicates research on the canons of the Constantinople Council, since the Russian or Greek authorship of every canon requires laborious verification.

2 Edition of the Greek text: Памятники древнерусского канонического права, ч. 1: памятники XI-XV веков [Old Russian Canon Law Texts, Part 1: Texts of the 11th-15th Centuries] (Русская историческая библиотека [Russian Historical Library], 6), ed. by A.S. Pavlov, St.

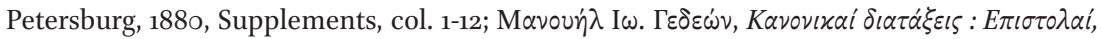

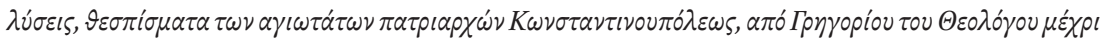

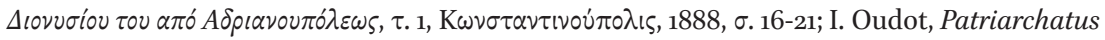
Constantinopolitani. Acta Selecta, vol. 1 (Fonti. Serie II - Fascicolo III), Vaticanis, 1941, p. 90-97. Editions of the Greek text in French translations: I. Oudot, Patriarchatus Constantinopolitani. Acta Selecta, vol. 1 (Fonti. Serie II - Fascicolo III), Vaticanis, 1941, p. 90-97; V. Laurent, Les Regestes de 1208 a 1309 (= V. Laurent, Les Regestes des Actes du Patriarcat de Constantinople, 1: Les Actes des Patriarches, fasc. 4), Paris, 1971, p. 213-215, № 1427. Editions in Old Russian: Памятники древнерусского канонического права [Old Russian Canon Law Texts], col. 129140; Энииклопедия русского игумена XIV-XV вв. Сборник преподобного Кирилла Белозерского. Российская Национальная Библиотека, Кирилло-Белозерское собрание, № $X I I$ [Encyclopedia of the Russian Hegumen of the 14th-15th Centuries. Miscellany of St. Cyril of White Lake. Russian National Library, Kirillo-Belozerskoje collection, No XII], ed. by G.M. Prokhorov, St. Petersburg, 2003, p. 88-91; and others.

3 A. Papadakis, Crisis in Byzantium. The Filioque Controversy in the Patriarchate of Gregory II of Cyprus (1283-1289), NY, 1997, p. 15-27.

4 Edition: Памятники древнерусского канонического права, col. 84-102. 
The canons of the Constantinople Council of 1276 are mainly devoted to questions regulating liturgical services. They examine the duties of clergymen belonging to different degrees of the church hierarchy, from deacon up to bishop and from a newly-invested monk up to hegumen. The Russian Church was in distress at the time of the Council as a result of the Mongol invasion. Desolation of a great number of churches and a lack of clergy led to situations when laymen, monks or clergymen were obliged to fulfill tasks outside of their typical roles in the church. For example they may have been asked to perform various sacraments or other rites without which church services would have ceased altogether. This factor is relevant to the liturgical functions of the hegumen.

There is no doubt that the majority of the problems in the Russian Church in the 13th century were connected with the loss of bishops, who were often absent for many years from many Russian dioceses. This led to a gradual fading of ecclesiastical life all along the vast expanse of the Russian territories. A hegumen could function as a kind of substitute for a bishop under these circumstances. At the minimum, he could perform some of the services of the annual cycle that are typically performed by a bishop. The canons of the Constantinople Council of 1276 describe four such services at which a bishop is appointed to read the Gospel himself: the Liturgy on Great Thursday, the Liturgy and vespers on Pascha, and the Liturgy on the Ecclesiastical New Year (September 1). The hegumen may read the Gospel on these feasts if there was no bishop present: one finds this in the Russian version of the canons of the Council of Constantinople, though the Greek version makes no mention of hegumens and discusses only bishops). ${ }^{5}$

The opposite was also possible according to the canons: the hegumen could be replaced by a bishop; for example, a bishop could entrust monastic vows in the absence of a hegumen, though usually the hegumen, if he was ordained, was the only person who could entrust vows according to the service of monastic

5 Памятники древнерусского канонического права, col. 131, No 1. 
tonsure. ${ }^{6}$ Exceptions to the canons could be made in case of a serious illness of the candidate for tonsure, when imminent death would not have allowed a delay the monastic tonsure even though a hegumen was absent. ${ }^{7}$ Russian hierarchs asked the Constantinople Council if a bishop could tonsure a dying man as an exception. The Greek bishops confirmed that any clergyman could tonsure a monk in such cases, not just a bishop, but even a church reader. ${ }^{8}$ It is known from other sources that sometimes dying monks tonsured themselves to the great schema, ${ }^{9}$ and in other cases a priest-monk would tonsure a dying layman. ${ }^{10}$

Only the question of tonsuring a dying bishop to the great schema was singled out, ${ }^{11}$ owing to its great importance, since a bishop could not maintain his episcopal see after taking the great schema. ${ }^{12}$ This means that the forced or compulsive tonsure of a bishop to the great schema led to the widowhood of the diocese even though the bishop remained alive and well and may have wanted to return to the bishopric. Thus the tonsuring of a bishop to the great schema was a crucial act that could be performed only in strict accordance with all of the necessary rules taking into account the significance of the decision. This act could be performed by a hegumen only - or in his absence by another bishop - not by a clergyman of a lower degree. In this instance the bishop fulfills the duties of a hegumen.

The main questions concerning hegumens at the Council of Constantinople focused on liturgical practice. Four questions are addressed in addition to those described above: the singing of the Trisagion with ripidia, the service of the Prothesis (Proskomedia), the rite of the Exaltation of the Cross, and the final prayers of the Divine Liturgy.

6 Б.А. Успенский, “Антоний Печерский и начальная история русского монашества (Рясофор в Древней Руси) [В.A. Uspenskij, St. Anthony of Kiev and the Earliest History of Russian Monasticism (Novitiates in Old Rus')]", Slověne, 2016, 5/1, pp. 96-98.

7 About conferring the monastic vows before death see: Б.А. Успенский, Ф.Б. Успенский, Иноческие имена на Руси [B.A. Uspenskij, F.B. Uspenskij, Monks' Names in Rus'], Moscow - St. Petersburg, 2017, pp. 203-221.

8 Памятники древнерусского канонического права, col. 133, № 9.

9 Успенский, Успенский, Иноческие имена на Руси, pp. 207-208.

10 Памятники древнерусского канонического права, col. 256-257.

11 Памятники древнерусского канонического права, col. 133, № 10.

12 Б.А. Успенский, Царь и патриарх. Харизма власти в России (Византийская модель и ее русское переосмысление) [B.A. Uspenskij, Tsar' and Patriarch. The Charisma of Power in Russia (The Byzantine Model and its Russian Interpretation)], Moscow, 1998, p. 272, footnote 26 . 
The first of these questions concerns the Liturgy as served both by bishops and hegumens: are hegumens allowed to celebrate the Divine Liturgy with ripidia and perform the singing of the Trisagion in the sanctuary? The text permits a hegumen to carry the Gifts accompanied by ripidia during the Great Entrance, but the hegumen should not make the sign of the cross over the Gifts with ripidia. ${ }^{13}$ Making the sign of the cross with ripidia is a feature of the hierarchical service, so according to the Canons of the Council of Constantinople, the hegumen may use ripidia only with the blessing of a bishop. Furthermore, a hegumen may make the sign of the cross at the altar while saying the prayer during the singing of the Trisagion by hand only, while a bishop makes the sign of the cross with the hierarchical candles, the dikerion and trikerion. ${ }^{14}$

Russian liturgical books describing the rite of a bishop or hegumen were absent at the end of the 13th century. The earliest Russian manuscript service book for a bishop is dated to the second half of the 14 th century. ${ }^{15}$ We can suppose that the features of the hierarchical service were known only through oral communication with the Greek metropolitans who visited Russia. Probably the features of a hegumen's rite were less well known than the features of the hierarchical rite, taking into account that the hegumen's rite did not attract as much attention as the rite of a bishop and it is thus not described in the service books. In the text describing performance of the Liturgy with ripidia, the hegumen's rite is likened to the hierarchical rite, so the functions of this highest degree of monk are similar to those of the bishop. It is the earliest written Russian evidence of making the sign of the cross with ripidia and the hierarchical candles.

The Service of the Prothesis (Proskomedia)

Another question directly connected to the functions of a hegumen is devoted to the service of the Prothesis (Proskomedia). It is one of the most important

13 Памятники древнерусского канонического права, col. 133, № 8.

14 R.F. Taft, The Precommunion Rites (A History of the Liturgy of St. John Chrysostom, 5), Rome, 2000 (осA, 261), pp. 184, 274, 277, 278; М.С. Желтов, “Чин Божественной литургии в древнейших (XI-XIV вв.) славянских Служебниках [M.S. Zheltov, The Rite of the Divine Liturgy in the Oldest (11th-14th Centuries) Slavonic Euchologia]", Богословские труды [Theological Proceedings], 41. Moscow, 2007, pp. 323-324.

15 М.С. Желтов, Чиновник архиепископов Новгородских. Древнерусский Требник Рнь, Cog. 1056 [M.S. Zheltov, The Euchologion of the Archbishops of Novgorod. The Old Russian Schematologion RNB, Sof. 1056], Moscow, 2017. (Литургическое наследие [Liturgical Heritage], 1), p. 10. 
parts of the Liturgy and one of the crucial differences between the StuditeAlexis Typicon and the Jerusalem Typicon. Such differences were behind the appearance of a number of articles about the Prothesis rite in the canons of the Constantinople Council of 1276. We find among others a question of whether it is possible for the hegumen to serve at the Prothesis in case several clergymen, including deacons and priests, concelebrate at the Divine Liturgy. The answer gives a strict hierarchy of clergy and states that if a hegumen is the senior among the clergymen performing the Liturgy, he blesses one of the deacons to serve the Prothesis rite; but if a bishop officiates at the Liturgy, then all the clergymen serve at the Prothesis rite together. ${ }^{16}$

This answer is given in accordance with the Studite Typicon, which treats the Prothesis as a preparatory stage to administering the Sacrament, and allows for it to be served by deacons. ${ }^{17}$ This practice was typical both in Byzantium and in Russia at an earlier stage, but by the second half of the 13th century it disappeared in the Greek church completely as part of the transition to the Jerusalem Typicon. ${ }^{18}$ The same change in the Russian church was much more slow and gradual. The Jerusalem Typicon prevailed in the Russian church only by the end of the 14th century; it was part of a set of liturgical reforms begun by Metropolitan Alexis and completed by Metropolitan Cyprian, ${ }^{19}$

16 Памятники древнерусского канонического права, col. 134, No 14.

17 С.Д. Муретов, “Чин проскомидии в Русской церкви с XII по XIV вв. (до митрополита Киприана) [S.D. Muretov, The Rite of the Proskomedia in the Russian Church from the 12th to the 14th Centuries]", in Чтения общества любителей древней письменности [Proceedings of the Society of Patrons of Old Literature], 1894, September, pp. 499-502; A.M. Пентковский, Типикон патриарха Алексия Студита в Византии и на Руси [A.М. Pentkovskiy, The Typicon of Patriarch Alexis the Studite in Byzantium and Rus'], Moscow, 2001, р. 275; Т.И. Афанасьева, Древнеславянские толкования на литургию в рукописной традииии ХII-ХVI вв. Исследования и тексты [T.I. Afanasyeva, Old Slavonic Commentaries of the Liturgy in the Manuscript Tradition of the 12th-16th Centuries. Studies and Texts], Moscow, 2012, p. 75 .

18 А.М. Пентковский, “Иерусалимский типикон в Константинополе в Палеологовский период [A.M. Pentkovskiy, The Jerusalem Typicon in Constantinople in the Palaeologan Period]", Журнал Московской патриархии [Journal of the Moscow Patriarchate], Moscow, 2003, 5, pp. 77-87; А.Ю. Виноградов, М.С. Желтов, “Первая ересь на Руси: Русские споры 116о-х годов об отмене поста в праздничные дни [A.J. Vinogradov, M.S. Zheltov, The First Heresy in Rus': Russian Quarrels Concerning Dispensation from Fasting on Festal Days in the 116os]", Древняя Русь. Вопросы медиевистики [Old Russia. Questions in Medieval Studies], Moscow, 2018, 3(73), p. 13 .

19 А.М. Пентковский, “Литургические реформы в истории Русской Церкви и их характерные особенности [A.M. Pentkovskiy, Liturgical Reforms in the History of the Russian Church and their Typical Features]", Журнал Московской патриархии [Journal of the Moscow Patriarchate], Moscow, 2001, 2, pp. 76-77; А.М. Пентковский, “Иерусалимский устав и его славянские переводы в XIV столетии [A.M. Pentkovskiy, The 
though some innovations of the Jerusalem Typicon became known in Russia much earlier. ${ }^{20}$ One of the first innovations was the prohibition to serve the Prothesis by a deacon; this canon is included in the resolutions of the Russian council that took place in Vladimir in $1273 .{ }^{21}$ It is obvious that while the Studite Typicon was in force in the Russian church, that is, during the 14th century, the prohibition for a deacon to serve the Prothesis could not be general. This situation is described in exactly this way in the observed text. The article is absent from the Greek text of the canons of the Constantinople Council; this decision could not have been made by Greek bishops, evidently, as they were already accustomed to the Prothesis served by the senior priest, not by the deacon. Undoubtedly this decision was offered by a Russian editor in the 14th century.

The Exaltation of the Cross

One more liturgical article in the canons of the Constantinople Council concerned the feast of the Exaltation of the Holy Cross, which had been established in Byzantium in commemoration of the discovery of the True Cross in Jerusalem in 326 . In memory of this event, the Cross is placed on the altar

Jerusalem Typicon and its Slavonic Translations in the 14th century]", in Преводите през XIV столетие на Балканите [Translations of the 14th Century in Balkans], Sofia, 2004, pp. 164, 168; Т.И. Афанасьева, “Литургическая реформа при митрополите Киприане и формирование Большого требника в Московской Руси [T.I. Afanasyeva, The Liturgical Reform of Metropolitan Cyprian and the Formation of the Great Euchologion in Muscovite Rus']", in Письменность, литература, фольклор славянских народов. История славистики. ХVI Международный съезд славистов. Доклады российской делегаиии [Writings, Literature, Folklore of the Slavic Nations. History of Slavic Studies. 16th International Congress of Slavic Scholars. Proceedings of the Russian Delegation], Moscow, 2018, pp. 20-33.

For example, Metropolitan Maxim, who came to the Kiev Metropolis from Constantinople, wrote a special Rule about fasts which is based on the Jerusalem Typicon. See:Памятники древнерусского канонического права, col. 140-142; М.В. Корогодина, “От поучения к уставной статье: судьба Правила митрополита Максима в XIV-XVI в. [M.V. Korogodina, From Sermon to Service Text: the Fate of the Rule of Metropolitan Maxim during the 14th-16th Centuries]", Древняя Русь. Вопросы медиевистики [Old Russia. Questions in Medieval Studies], Moscow, 2017, 3 (69), pp. 58-59.

Памятники древнерусского канонического права, col. 96-97, No 4; М.M. Бернатский, М. Желтов, “Вопросоответы митрополита Илии Критского: Свидетельство об особенностях совершения Божественной литургии в начале XII века [M.M. Bernatsky, M. Zheltov, Questions-and-Answers of Metropolitan Elias of Crete: A Testimony to the Celebration of the Divine Liturgy in the Early 12th Century]", Вестник Православного Свято-Тихоновского гуманитарного университета [Bulletin of the St. Tikhon's Orthodox University for the Humanities], I: Theology, Philosophy, 2005, 14, p. 27. 
during the Divine Liturgy on September $14 .{ }^{22}$ The main question is who should perform this solemn action of placing the Cross: "If there is not a bishop in the town is it permitted for the hegumen to place the Cross?". ${ }^{23}$ It is the only article with a direct reference to the Studite Typicon and it allows the hegumen to perform this action: "It is not forbidden by the canons of Theodore the Studite". According to the Studite Typicon, the hegumen serves the Divine Liturgy on the feast of the Exaltation of the Cross. ${ }^{24}$ This tradition is reflected also in the "Questions of Kirik". ${ }^{25}$ The question means that a bishop is the main figure in the service, so it is rather unusual, as there is no bishop's service on the day of the Exaltation of the Cross either in the Studite or in the Jerusalem Typica. We can suggest that it is a local Russian tradition for a bishop to serve on this feast. Russian episcopal Euchologia did not exist in this early period, so the bishop's services were regulated by local oral tradition. The reference to the Studite Typicon unequivocally indicates that the text, lacking in the Greek version of the canons, was added in Russia and did not belong to the original canons of the Council of Constantinople. Probably it was added in the 14th century.

\section{The Final Prayers at the Divine Liturgy}

The next article concerns the question of the location of the hegumen in the church at the end of the Liturgy. It mentions the hegumen's "place" in the church. The answer indicates two decisions, depending on the status of the hegumen during the Liturgy, since he can attend the Liturgy as a monk, dressed in a mantle, or as a presbyter performing the service, dressed in a phelonion. ${ }^{26}$ In the second case, the hegumen was a presbyter and stood during the prayers at the place intended for a priest performing the Divine Liturgy, more specifically, in the Holy Gates. In the first case, the hegumen functioned as a monk, and in accordance with this he took the special place intended for the head of a monastic community. This canon was relevant in medieval Russia, where

\footnotetext{
22 L. van Tongeren, Exaltation of the Cross: Towards the Origins of the Feast of the Cross and the Meaning of the Cross in Early Medieval Liturgy, Leuven, 2000.

23 Памятники древнерусского канонического права, col. 135, № 18.

24 Пентковский, Типикон патриарха Алексия Студита, p. 408.

25 В.В. Мильков, Р.А. Симонов, Кирик Новгородеи:ученый и мыслитель [V.V. Milkov, R.A. Simonov, Kirik of Novgorod: a Scholar and Thinker], Moscow, 2011, p. 367, К 21. (Памятники древнерусской мысли. Исследования и публикации, 7 [Monuments of Old Russian Thought. Studies and Editions, 7]).

Памятники древнерусского канонического права, col. 134-135, № 16.
} 
many hegumens were not priests ${ }^{27}$ and could not perform the Liturgy themselves. However it is evident that the hegumen may be present at the Liturgy simply to pray and not to officiate, even if he was a priest.

This article pays special attention to the separate "place" of the hegumen in the church. Bishops and priests serving the Liturgy were placed in the altar, regardless of their real participation in the service. Monks, on the contrary, were in the middle nave (vaós) of the church, in front of the iconostasis and altar; this would also be the place of a hegumen if he attended the Liturgy as a monk in a mantle, rather than as a priest in a phelonion. All the Typica intended a special place for monks and the hegumen in the middle nave. According to the Studite Typicon, the hegumen should stay in the middle nave on the right side, in front of the altar: "it is decreed that hegumens are to stay on the right side". ${ }^{28}$ The organization of special places for monks became more important after the acceptance of the Jerusalem Typicon, as its characteristic feature is the long all-night vigils. Such special monk's places were created in the Eastern Orthodox monasteries and got the name stasidia. These are special places with seats and elbow-rests for prayers used both in Greece ${ }^{29}$ and on Mt. Athos. Every stasidios in Athonite monasteries had its own occupant, and the stasidios of a hegumen was marked out from among the others. ${ }^{30}$ There is a

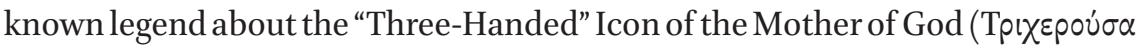
or Trojerutchitza), which took the hegumen's place in the Chilandar Monastery on Mt. Athos and so became the superior of the monastery. ${ }^{31}$ The stasidia

27 Успенский, “Антоний Печерский и начальная история русского монашества”, pp. 9798 , footnote 46 .

28 Пентковский, Типикон патриарха Алексия Студита, p. 402 (the chapter "Concerning the Standing of Monks in the Church").

29 Н.Д. Успенский, “Чин всенощного бдения ('Н $\alpha \gamma p v \pi v i \alpha)$ на православном Востоке и в Русской Церкви [N.D. Uspenskij, The Rite of the All-Night Vigil ('H $\alpha$ үрuлvía) in the Orthodox East and in the Russian Church]", in Богословские труды [Theological Proceedings], Moscow, 1978, 18, pp. 65-106.

3 М.М. Клименко, "Особенности совершения всенощного бдения в монастырях святой Горы Афон [M.M. Klimenko, Features of the Serving of the All-Night Vigil in the Monasteries of the Holy Mount Athos]", in Богословские труды [Theological Proceedings], Moscow, 1997, 33, pp. 110-137.

$3^{1} \quad$ I. Bentchev, "Die Dreihändige Gottesmutterikone im Hilandar-Kloster auf Athos", in Hermeneia. Zeitschrift für ostkirchliche Kunst, Bochum, 1993, 1, ss. 46-52 (for a more comprehensive Russian version of the paper see: И. Бенчев, "Икона Богоматери Троеручицы в Хиландарском монастыре на Афоне [I. Bentchev, The Icon of the Three Handed Mother of God in the Chilandar Monastery on Athos]", in Византия и византийские традищии. Сб. науч. трудов, посвященный ХІх международному конгрессу византинистов [Byzantium and Byzantine Traditions. Proceedings of the 19th Interna- 
were not widespread in Russia; some analogues in the form of carved armchairs appeared rather late and are not maintained properly today. ${ }^{22}$

The question about the hegumen's place is probably also connected with the Studite Typicon, according to which the hegumen is a main participant at every church service, even if he is only present at the Liturgy and does not officiate at it himself. Describing the daily cycle of services and the services for some great feasts, the Studite Typicon emphasized that the hegumen's role was different from the role of the priest that served the Liturgy, as it was not a requirement for the hegumen to be a priest..$^{33}$ The question about the location of the hegumen is connected with the attention to his function and actions during the Liturgy, as the hegumen could bless the prayers if he performed the divine service by himself, or he could take the blessing with the other monks if he was dressed only in the mantle. The Jerusalem Typicon does not pay so much attention to the functions of the hegumen and does not describe his actions during different parts of the Liturgy.

The Greek text of the canons of the Council of Constantinople of 1276 does not have any special questions about hegumens, so all of these questions must have appeared in the Russian text. References and parallels to the Studite Typicon provide evidence that the canons concerning hegumens were added to the original Greek text by Russian authors: here we must take into account that the Studite Typicon had lost its authority in the Orthodox East, but was still accepted in Russia at the end of the 13th and during the 14th centuries. Such additions that contradicted the canons of the Russian Council of 1273 could be

tional Congress of Byzantinists ], Copenhagen, 18-24 of August, 1996, St. Petersburg, 1996, pp. 175-183); М. Тatiћ-Ћupiћ, “Тројеручица светога Саве и њен култ у православном свету [Three Handed Mother of God of St. Sava and her Veneration in the Orthodox East]", in Сборник радова [Collection of Documents], Beograd, 1997, pp. 133-16o.

The hegumen's seat in the Svensky Dormition monastery, dated to the end of the 16th or beginning of the 17th centuries, no longer extant. A photograph of the beginning of the 2oth century depicts the hegumen's seat placed in the middle of the nave opposite the main icon of the church. See: M.С. Знаменский, “Свенский монастырь [M.S. Znamenskij, Svensky Monastery]”, Старые годы [Old Years], 1915, July - August, p. 91. Several photos of Svensky monastery are published by Znamenskij in the same paper on unnumbered pages.

33 Пентковский, Типикон патриарха Алексия Студита, pp. 242, 252, 316 and others. See especially the chapter "About hegumens" of the Studite Typicon: Ibid, p. 393. 
made only in a diocese far from the authority of the Metropolitan. The Jerusalem Typicon and other new service books came to such distant dioceses in the 14th century very slowly, which explains why such anachronistic views on the liturgical function of the hegumen were maintained in Russian texts in the 14th and 15th centuries. 